\title{
Evaluation of Student Development Programs in the State Universities and Colleges of Samar Island
}

\author{
Ronaldo A. Amit \\ University of Eastern Philippines, Catarman, Northern Samar, Philippines
}

\begin{abstract}
How to cite this paper: Ronaldo A. Amit "Evaluation of Student Development Programs in the State Universities and Colleges of Samar Island" Published in International Journal of Trend in Scientific Research and Development (ijtsrd), ISSN: 24566470, Volume-3 | Issue-3, April 2019, pp.474-477, URL: http://www.ijtsrd.co $\mathrm{m} /$ papers/ijtsrd 229 20.pdf

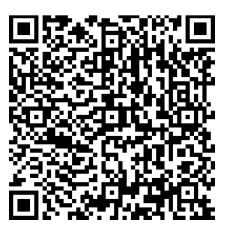

IITSRD22920

Copyright (C) 2019 by author(s) and International Journal of Trend in Scientific Research and Development Journal. This is an Open Access article distributed under the terms of the Creative Commons

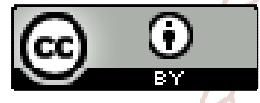
Attribution License (CC BY 4.0) (http://creativecommons.org/licenses/ by/4.0)
\end{abstract}

\section{INTRODUCTION}

Higher, post-secondary, tertiary, or third level education is the stage of learning that occurs at universities, academies, colleges, seminaries, and institutes of technology. Higher education also includes certain college-level institutions, such as vocational schools, trade schools, and career colleges that award academic degrees or professional certifications (Bakvis and Cameron, 2006).

The right of access to higher education is mentioned in a number of international human rights instruments. The UN International Covenant on Economic, Social and Cultural Rights of 1966 declares, in Article 13, that "higher education shall be made equally accessible to all, on the basis of capacity, by every appropriate means, and in particular by the progressive introduction of free education". In Europe, Article 2 of the First Protocol to the European Convention on Human Rights, adopted in 1950, obliges all signatory parties to guarantee the right to education (Bakvis and Cameron, 2006).

Higher education and student affairs and services, as integral partners in providing services and programs, must be student centered and include students as partners and responsible stakeholders in their education. Students must be at the table with other higher education decision-makers at the institution, government and UNESCO levels including follow-up conferences and meetings related to the WCHE. Students have the right and responsibility to organize themselves to participate in governance and to pursue their personal and social interests (Ludeman, 2002).

Thus, higher education must address the personal and developmental needs of the student as a human being. Student affairs and services should take the lead in this regard, as well as appropriate advocacy of students in general based on a number of critical values including worth of the individual, diversity, pluralism, inclusiveness, community, high expectations, a global view, citizenship and leadership, ethical living, and the idea that students can and must participate actively in their growth and development (Ludeman, 2002).

Student Development Programs and Services refer to the services and programs designed for the exploration, enhancement and development of the student's full potential for personal development, leadership and social responsibility through various institutional and/or studentinitiated activities (CHED, Memo 2013). These are the following: Cultural Development Program, Leadership Training Program, Multi-Faith Services, Social and Community Development Program, Sports Development Program, Student Organization and Services, Student Publications, and Student/Council Government.

Student services offered in educational institutions have an important role in addressing the needs of the students. An 
array of student services program is organized under the rubric of a framework of student development that complements the instructional roles of the formal academic program.

Em (1993), as cited by De Asis, described that the role of student services is to provide leadership in helping develop a true community of learning by expanding the intellectual, social, and cultural horizons of the student body through a broad range of support services and programs outside the formal academic setting (De Asis, 2012).
Learning takes place not only inside the classroom. It also takes place outside the classroom. Yu (2000) affirmed that to enhance students' whole person development and to foster and enriched campus life, there should be organized training courses (development workshops) for students. These courses are not part of the required curriculum and do not carry credits. These are, however, meant to facilitate the students' holistic development and perceived as complementary contribution to the students' academic success. They see to it that they meet the "student-centered" principle in order to attract student patronage among all the other competing attractions in the university.

\section{METHODOLOGY}

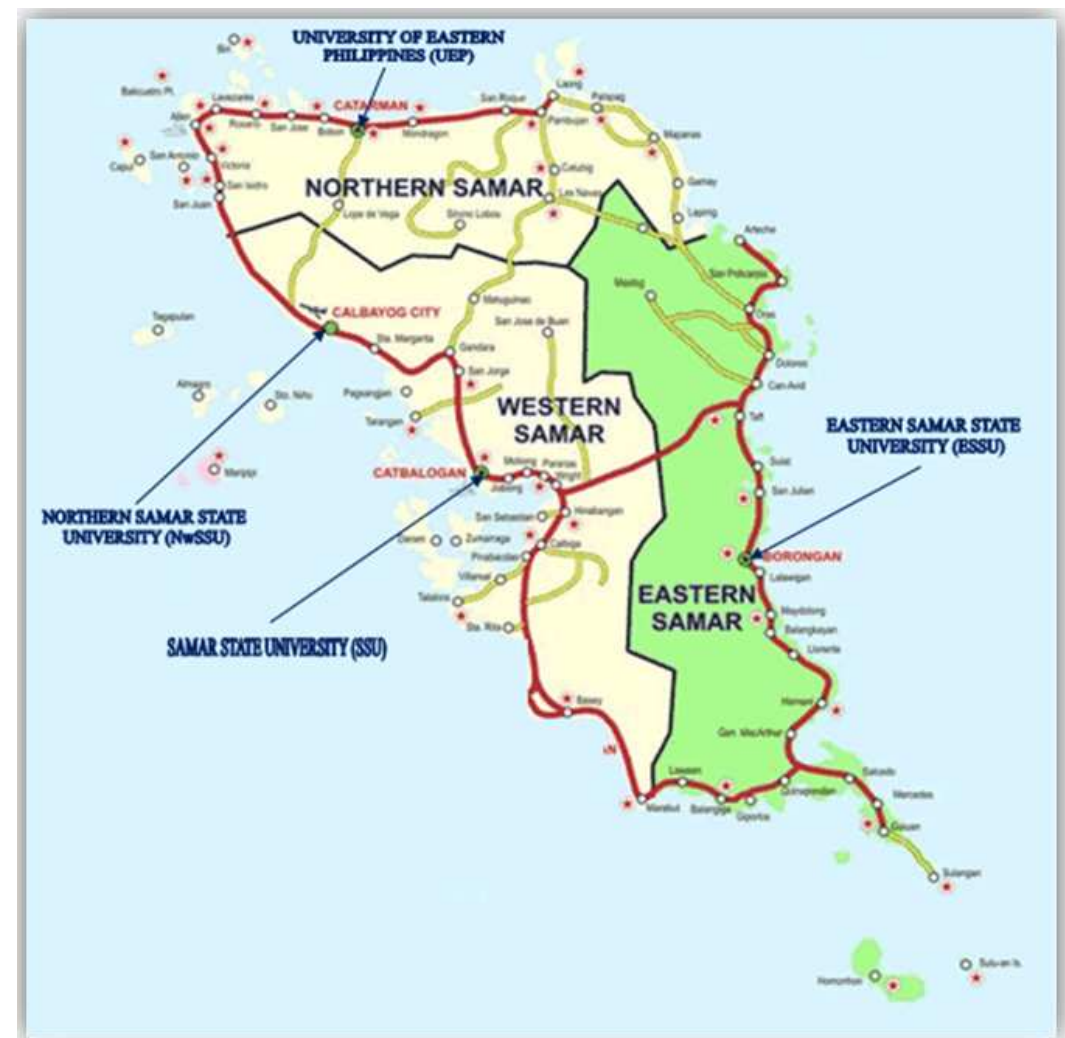

Figure1. Administrative map of Samar Island showing the location of sampled universities

The descriptive-evaluative method of research was utilized in this study. The descriptive data were obtained from the respondents who were chosen through complete enumeration for presidents, deans/directors and personnel and random sampling for the students, respectively. This study was conducted in state universities that are situated in Samar Island, namely: the University of Eastern Philippines Main Campus (Catarman), North West Samar State University Main Campus (Calbayog City), Samar State University Main Campus (Catbalogan City) and Eastern Samar State University Main Campus (Borongan City).

\section{RESULTS AND DISCUSSION}

The students' development programs and services include cultural development program, leadership training program, multi-faith services, social and community development program, sports development program, student organization and services, student publications, and student/council government.

The cultural development program offered by the Office of the Student Affairs as assessed by the respondents was rated very satisfactory. This means that the respondents were very satisfied with the different activities, develop and enhance the students' creativity and skills through adequate programs for student exposition of talents such conduct of cultural shows and field demo. Also on the provision of audition and selection criteria for membership in the dance troupe, choir, dramatic, etc. and programmed training for interested students.

In terms of leadership training program, it was rated as very satisfactory. This means that the respondents were very satisfied with the different programs and opportunities offered for personal and organizational effectiveness. This further indicates satisfaction on the following indicators: mentors and coaches students on their current leadership work, targets students who have yet been made aware of opportunities in student organizations or in the concept of personal leadership in general, caters to members of organizations who want or are discerning whether to take an active role in their respective organizations, and aids student leaders to hurdle the stress and challenges of being leaders.

Likewise, the multi-faith services it was rated very satisfactory. This means that the respondents were very 
satisfied on the assistance provided to the students of the different state universities in the Samar Islands in their spiritual enrichment. This further indicates that the respondents are very satisfied on the spiritual enrichment programs and activities through ecumenical services and youth encounter activities (i.e., recollection, etc.), leadership seminar, assembly, and other spiritual and religious enrichment based workshops, lectures, and outreach programs which provides an opportunity for individual students to live, share and express their faith as appropriate, and identifies core groups of students and faculty interested in exercising their religious freedom.

The social and community development program as assessed by the respondents was rated as very satisfactory. This means that the respondents were very satisfied on the programs and opportunities designed to develop social awareness, personal internalization and meaningful contribution to nation building of the students in the Island of Samar. This further indicates that the respondents were very satisfied with the different programs develops in which students learn and develop through didactic course work and organized service experiences that meet community needs, trains volunteers how to move into a service project focusing on attitude, work ethic, cross-cultural sensitivity, follow through, liabilities and risks, etc., provides our communities with students who are willing to address social issues through volunteerism, provides students an opportunity to understand community social issues, markets opportunities for students to get involved with community service and volunteer activities, affords students the chance to reflect on community-service learning experiences so they may relate them to their own personal development, and conducts studies on the value of community-service learning.

In like manner, the sports development program also got a rating of very satisfactory. This means that the respondents were very satisfied with the different programs designed to promote physical fitness and wellness of the students. This also indicates that they were very satisfied with the developed and conducted sports, recreation, intramural programs, and other athletic and non-athletic events and activities based on a student-centered philosophy emphasizing the overall quality of life. Furthermore, they are also satisfied with the adequate training for the athletes, financial support and/or scholarships available for deserving athletes, proper implementation of policies and procedures in selecting athletes, provision of organized schedule of athletes' activities, provision of the necessary facilities, equipment, supplies, and materials for the Sports Services Unit, and regular monitoring and evaluation of sports activities.

Moreover, the student organization and services was also rated by the respondents as very satisfactory. This means that the respondents were very satisfied with the provision of guidelines and criteria for proper recognition of student organization and availability of well-organized co-curricular activities. They were also satisfied with the support from the administration and faculty in the conduct of activities and implementation of plans and projects, selection of qualified faculty advisers for the different student organizations, and monitoring the conduct of activities of the different student organization by the advisers and school officer-in-charge such as leadership seminars.
The student publications as assessed by the respondents which is interpreted as very satisfactory means that the respondents were very satisfied with the training provided for the student journalist and promotion and development of campus journalism that addresses the needs and interest of students in the Island of Samar. They were also satisfied with the publication highlights and documents the students' achievements, activities and performance in both academic and non-academic endeavors, publication of articles that promote development and growth of students, dissemination of guidelines/editorial policies, publication office provided with the necessary facilities, equipment, supplies and materials, publication of articles reflect the students' ideas opinions and concerns, implementation of guidelines/editorial polices (i.e., number of publication/issues prescribed were meet), and screening and selection of editorial board

And the student/council government was also assessed by the respondents with a very satisfactory rating means that the respondents were very satisfied on the recognition of the HEI's on the right of the students to govern themselves and to be represented in appropriate student councils, or board of regents or trustees. This further indicates that they were satisfied with the involvement and enthusiasm of all the students in the affairs of the university and/or colleges, promotion and strengthening common ties among students, student groups and organizations, and other sectors of the university and the society, by serving as a vehicle to express students ideals, hope and aspirations, and for promoting the students' common good.

The status of implementation of the students' development programs and services were very satisfactory to the SUC presidents, deans of student affairs and students. This means that the services and programs designed for the exploration, enhancement, and development of the student's full potential for personal development, leadership, and social responsibility through various institutional and/or studentinitiated activities were well-implemented in state universities in Samar Island.

This confirms with the CHED Memorandum Order No. 9 Series of 2013 that the educational institution should seek to form individuals who can later become productive citizens of the country and the world. Higher education institutions must provide a set of student-centered activities and services in support of academic instruction, intended to facilitate holistic student development for active involvement in nation-building.

Em (1993) asserted that the role of student services is to provide leadership in helping develop a true community of learning by expanding the intellectual, social, and cultural horizons of the student body through a broad range of support services and programs outside the formal academic setting.

This confirms with Byrd statement that student affairs should provide excellent student development programs and activities for the university's diverse student population and unique educational experience by fostering an environment where students can address and solve their problems, as well as explore and test their values, interests and skills. 


\section{CONCLUSION}

The student development programs as regards to the implementation is rated very satisfactory. This implies that the services and programs designed for the exploration, enhancement and development of the student's full potential for personal development, leadership, and social responsibility are well-implemented.

Another, the researcher came across with the insufficiency in budget allocation among the sample universities. It is the major problem in the implementation of the student development programs and services. This implies that a lot of programs and activities are not yet provided and implemented or given to make its clientele appreciate the program and activities as reflected in the action plan.

\section{References}

[1] Bobsworth, K. (2009). Major in Asian language and culture. UBC Calendar. 10.

[2] Bryson, J. M. (2008). Strategic planning for public and non-profit organizations: A guide to strengthening and sustaining organizational achievement. San Francisco, United States: Jossey-Bass Publishers, Inc.

[3] Buller, JL. (2002). The essential academic dean: $A$ practical guide to college leadership. New Jersey, United States: Prentice Hall, Inc.
[4] Chickering, AW, Reisser, L. (2003). Education and identity. Second Edition. San Francisco, California: Jossey-Bass Publishers, Inc.

[5] Evans, NJ, Forney, DS, DiBrito, F. (2008). Student development in college: Theory, research, and practice. San Francisco, California: Jossey-Bass Publishers, Inc.

[6] Martin, J. (2006). Organizational behavior and management. Third Edition. University of Hull.

[7] McPherson, M. S., Schapiro, M. O. (2002). The blurring line between merit and need in financial aid. Change. $34(2)$.

[8] O'Donnelly, J. P. (2012). Fundamentals of management, Ninth Edition. Kenya University.

[9] Patterson, J. C. H. (2008). Counseling and guidance in school: A first course, Revised Edition. New York, United States: Hamper and Row Publishers.

[10] Rhatigan, JJ. (2010). The handbook of student affairs administration: The history and philosophy of student affairs, Revised Edition. San Francisco, California: Jossey-Bass Publishers, Inc.

[11] Robbins, SP. (2001). Organizational behavior, Ninth Edition. New Jersey: Prentice Hall, Inc.

[12] Smith, J.M. (2008). The evolution of sex. Massachusetts, United States: Cambridge University Press. 